\title{
MANAJEMEN MUTU SMK MA'ARIF NU 1 BENER PURWOREJO DALAM MENINGKATKAN MUTU PENDIDIKAN DAN KEPERCAYAAN MASYARAKAT
}

\begin{tabular}{|c|c|c|}
\hline $\begin{array}{c}\text { Agus Muzamil } \\
\text { (SMK Maarif NU 1 Bener Purworejo) } \\
\text { agosmuzamel@gmail.com }\end{array}$ & $\begin{array}{c}\text { Eliyanto } \\
\text { (PPs IAINU Kebumen) } \\
\text { doktoreliyanto@gmail.com } \\
\end{array}$ & $\begin{array}{c}\text { Tursini } \\
\text { (MTs N8 Kebumen) } \\
\text { putrinabila7663@gmail.com }\end{array}$ \\
\hline
\end{tabular}

\section{ABSTRAK}

Penelitian ini didasari oleh pentingnya manajemen mutu sekolah. Sehubungan dengan hal tersebut, penelitian ini bertujuan untuk mengetahui Manajemen Mutu SMK Maarif NU 1 Bener Purworejo dalam Meningkatkan Mutu Pendidikan dan Kepercayaan Mayarakat. Penelitian ini merupakan penelitian kualitatif. Pengumpulan data menggunakan wawancara, observasi, dan dokumentasi, dan keabsahan data menggunakan triangulasi, dan teknik analisis data meliputi pegumpulan data, reduksi data, penyajian data, dan penarikan kesimpulan. Penelitian ini menghasilkan empat kesimpulan: (1) Perencanaan SMK Maarif NU 1 Bener Purworejo dalam meningkatkan mutu pendidikan dan kepercayaan masyarakat yaitu: Pertama, Penetapan standar mutu, yang mengacu pada 8 Standar Nasional Pendidikan. Kedua, Pemetaan mutu, yang didasarkan pada hasil Evaluasi Diri Sekolah dan SNP (Standar Nasional Pendidikan). Ketiga, Penyusunan rencana pemenuhan mutu. (2) Pelaksanaan SMK Maarif NU 1 Bener Purworejo dalam meningkatkan mutu pendidikan dan kepercayaan masyarakat dilakukan melalui pemenuhan Standar Isi, Standar Proses, Standar Kompetensi Lulusan, Standar Pendidik dan Tenaga Kependidikan, Standar Sarana dan Prasarana, Standar Pengelolaan, Standar Penilaian Pendidikan, Standar Pembiayaan. Selanjutnya, seluruh komponen sekolah juga memiliki komitmen tinggi dalam pelaksanaan pemenuhan mutu tersebut. (3) Evaluasi SMK Maarif NU 1 Bener Purworejo dalam meningkatkan mutu pendidikan dan kepercayaan masyarakat dilakukan melalui Evaluasi Diri Sekolah. Pada tahap ini, sekolah menyusun instrumen evaluasi kemudian membentuk tim pelaksana evaluasi. (4) Tindak Lanjut SMK Maarif NU 1 Bener Purworejo dalam meningkatkan mutu pendidikan dan kepercayaan masyarakat dilakukan sebagai suatu siklus yang berkelanjutan, yaitu melalui: Corrective Action, tindakan perbaikan ini dilakukan jika hasilnya tidak mencapai apa yang telah ditargetkan; dan Standardization Action, tindakan perbaikan ini dilakukan jika hasilnya mencapai target yang telah ditetapkan.

Kata kunci: Manajemen Mutu, Sekolah Menengah Kejuruan, Mutu Pendidikan, dan Kepercayaan Masyarakat.

\section{A. PENDAHULUAN}

Pendidikan memiliki peran penting bagi kemajuan suatu bangsa. Pendidikan yang bermutu sebagai harapan bangsa harus senantiasa diupayakan. Berbagai komponen dan pola pendidikan mulai dari visi, misi, tujuan, kurikulum, guru, metode, pola hubungan guru murid, evaluasi, sarana prasarana, lingkungan, dan evaluasi pendidikan harus didasarkan pada tujuan pendidikan nasional. Jika berbagai komponen tersebat satu dan lainnya membentuk suatu sistem yang baik, maka sistem tersebut selanjutnya dapat disebut sebagai sistem pendidikan yang berkualitas/bermutu.

Pendidikan adalah proses mendorong publik untuk berilmu pengetahuan dan memahami cara menggunakan akal atau logika dan pandangan dalam mengembangkan diri 
sendiri dan masyarakat. Serta menggunakan pengalaman dalam mengembangkan atau memakmurkan cara hidup, masyarakat dan bangsa. Melalui Pendidikan yang bermutu akan terbentuk manusia yang berkepribaian sejati yang semua aspek aspek kehidupannya berlandaskan kepada nilai-nilai kebaikan dan kebenaran.

Diperlukan adanya Manajemen pendidikan yang bermutu. Dimana manajemen penddikan pada hakikatnya adalah suatu proses penataan kelembangaan pendidikan yang melibatkan sumber daya manusia dan non manusia dalam menggerakkannya untuk mencapai tujuan secara efektif dan efisien. Proses penataan ini akan melibatkan pelaksanaan beberapa fungsi manajenem yang oleh pakar manjemen pendidikan sering disebut sebagai (planning, organaizing, actuating, dan controling).

Dalam perspektif Islam Istilah manajemen dijumpai kata al-Tadbir (pengaturan). Manajemen berdasar dari bahasa Inggris, yaitu dari kata to manage yang berarti mengurus, mengatur, melaksanakan, mengelola, dan memperlakukan. Kata ini merupakan derivasi dari kata dabbara (mengatur) yang banyak terdapat dalam al-Quran seperti firman Allah Swt: QS as Sajdah /32:5 yang terjemahnya : Dia mengatur urusan dari langit ke bumi, kemudian (urusan) itu naik kepadanya dalam satu hari yang kadarnya adalah seribu tahun menurut perhitunganmu. "Manajemen adalah Kegiatan seseorang dalam mengatur organisasi, lembaga atau sekolah yang bersifat manusia maupun non manusia, sehingga tujuan organisasi, lembaga atau sekolah dapat tercapai secara efektif dan efesien".

Keteraturan alam raya ini merupakan bukti kebesaran Allah swt. dalam mengelola alam semesta. Akan tetapi dalam konteks ini, Allah telah menciptakan manusia dan telah dijadikannya sebagai khalifah (pemimpin) di bumi, maka manusia diberikan tugas dan tanggung jawab untuk mengatur dan mengelola bumi dengan sebaik-baiknya sebagaimana Allah mengatur alam raya beserta isinya. Ajaran Islam memerintahkan kepada umatnya untuk dapat mengerjakan segala aktivitas yang baik harus dilakukan secara rapi, benar, tertib, dan teratur sesuai dengan proses yang diperintahkan.

Penjelasan tersebut menunjukkan bahwa hakikat manajemen adalah menata dan mengatur terhadap segala sesuatu kegiatan agar dapat dilakukan dengan sebaik mungkin, tepat, terarah, dan tuntas serta dapat dipertanggung jawabkan, kegiatan untuk menata, mengatur, atau mengelola merupakan hal yang disyariatkan dalam ajaran Islam.

Salah satu tugas yang diemban oleh pendidikan adalah mewariskan nilai-nilai luhur budaya kepada siswa dalam upaya membentuk kepribadian intelek yang bertanggung jawab melalui jalur pendidikan. Dan lembaga yang dipercaya oleh masyarakat ini adalah sekolah. Nilai-nilai yang dikembangkan di sekolah, tentunya tidak dapat dilepaskan dari keberadaan sekolah itu sendiri sebagai organisasi pendidikan, yang memiliki peran dan fungsi untuk mengembangkan, melestarikan dan mewariskan nilai-nilai budaya kepada para siswanya.

\footnotetext{
${ }^{1}$ Nazarudin. Manajemen Pembelajaran: Implementasi Konsep, Karakteristik, dan Metodologi Pendidikan Agama Islam. (Yogyakarta: Teras, 2007), hlm. 12.
} 
Oleh karena suatu organisasi terbentuk dari kumpulan individu yang berbeda baik sifat, karakter, keahlian, pendidikan, dan latar belakang pengalaman, maka perlu ada penyatuan pandangan yang akan berguna untuk pencapaian misi dan tujuan organisasi tersebut, agar tidak berjalansendiri-sendiri. Penyatuan pandangan dari sumber daya manusia di dalam organisasi ini diperlukan dalam bentuk ketegasan dari manajemen, penyatuan pandangan ini dituangkan dalam bentuk budaya organisasi yang akan mencerminkan spesifikasi dan karakter organisasi tersebut.

SMK Ma`arif NU 1 Bener adalah sebuah sekolah milik warga NU di Kabupaten Purworejo pada khususnya dan masyarakat Indonesia pada Umumnya, bukanlah milik yayasan pribadi. SMK Ma`arif NU 1 Bener Mendidik Taruna Taruni dengan kurikulum dari Dinas Pendidikan dan Kurikulum Pondok Pesantren (Kitab Kuning) dengan tujuan untuk Mencetak Generasi Islam yang CERDAS, DISIPLIN RELIGIUS, dan BERKARAKTER, sehingga menjadi generasi Islam yang ahli fikir dan dzikir (definisi cerdas dalam perspektif Islam dalam Al-Qur'an).

Berdasarkan latar belakang di atas peneliti tertarik untuk mengadakan penelitian dengan judul "Manajemen Mutu SMK Ma`arif NU 1 Bener Purworejo dalam Meningkatkan Mutu Pendidikan dan Kepercayaan Masyarakat.”

\section{B. KAJIAN LITERATUR}

\section{Manajemen Mutu}

Secara konseptual manajemen mutu dapat diterapkan baik pada barang maupun pada jasa, karena yang ditekankan dalam penerapan manajemen mutu adalah penerapan sistem mutu. Dengan demikian yang perlu diperhatikan dalam pengembangan manajemen mutu adalah pengembangan sistem mutu yang terdiri dari perencanaan sistem mutu, pengendalian sistem mutu, dan peningkatan sistem mutu. ${ }^{2}$

Adapun yang menyangkut hakikat mutu dalam pendidikan adalah: (a) Menciptakan konsistensi tujuan. (b) Mengadopsi filosofi mutu total. (c) Mengurangi kebutuhan pengujian. (d) Menilai bisnis sekolah dengan cara baru. (e) Memperbaiki mutu dan produktifitas serta mengurangi biaya. (f) Belajar sepanjang hayat. (g) Kepemimpinan dalam pendidikan. (h) Mengeliminasi rasa takut. (i) Menciptakan budaya mutu. (j) Perbaikan proses. (k) Membantu siswa berhasil. (I) Komitmen. (m) Tanggung jawab.

Berkaitan dengan hal itu, perguruan tinggi khususnya di Indonesia sudah saatnyalah melakukan reorientasi dan definisi tujuan dari pendidikan bahwa bukan yang menjadi prioritas sekedar untuk menghasilkan lulusan sebanyak-banyaknya tanpa peduli dengan kepuasan pelanggan atau pengguna lulusan tersebut namun yang terpenting bagi pendidikan tinggi adalah harus bertanggungjawab untuk menghasilkan output (lulusan)

\footnotetext{
${ }^{2}$ Vincent Gaspersz. Pedoman Implementasi Program SIX SIGMA Terintegrasi dengan ISO 9001 : 2000, MBNQA, dan HACCP. (Jakarta: Gramedia Pustaka Utama, 2002), hlm. 376.
} 
yang kompetitif dan berkualitas agar memuaskan kebutuhan pengguna tenaga kerja terampil, berpendidikan tinggi dan berwawasan luas.

Manajemen mutu merupakan serangkaian kegiatan yang dijalankan dalam manajemen berdasarkan fungsinya masing-masing dan mengikuti tahapan-tahapan tertentu dalam pelaksanaannya. ${ }^{3}$ Pembagian fungsi-fungsi manajemen bertujuan: (a) Supaya sistematika urutan pembahasannya lebih teratur, (b) Agar analisis pembahasannya lebih mudah dan lebih mendalam, (c) Untuk menjadi pedoman pelaksanaan proses manajemen bagi manajer. Namun demikian, secara umum perbedaan-perbedaan tersebut mempunyai titik temu dalam menyebutkan fungsi-fungsi manajemen, sebagaimana dalam manajemen mutu William Edwards Deming yaitu: Plan, Do, Check, Act.

PDCA adalah singkatan dari Plan, Do, Check, dan Act yaitu siklus peningkatan proses (Process Improvement) yang berkesinambungan atau secara terus menerus seperti lingkaran yang tidak ada akhirnya. Konsep siklus PDCA (Plan, Do, Check dan Act) ini pertama kali diperkenalkan oleh seorang ahli manajemen kualitas dari Amerika Serikat yang bernama William Edwards Deming.

PDCA (Plan, Do, Check, Act) atau disebut juga filosofi Deming, merupakan manajemen perbaikan mutu secara berkesinambungan, yang menekankan pada keuntungan jangka pendek, menengah, dan panjang. Deming juga mempelopori konsep SPC (Statistical Process Control), yang merupakan konsep dalam perbaikan kualitas berkesinambungan.

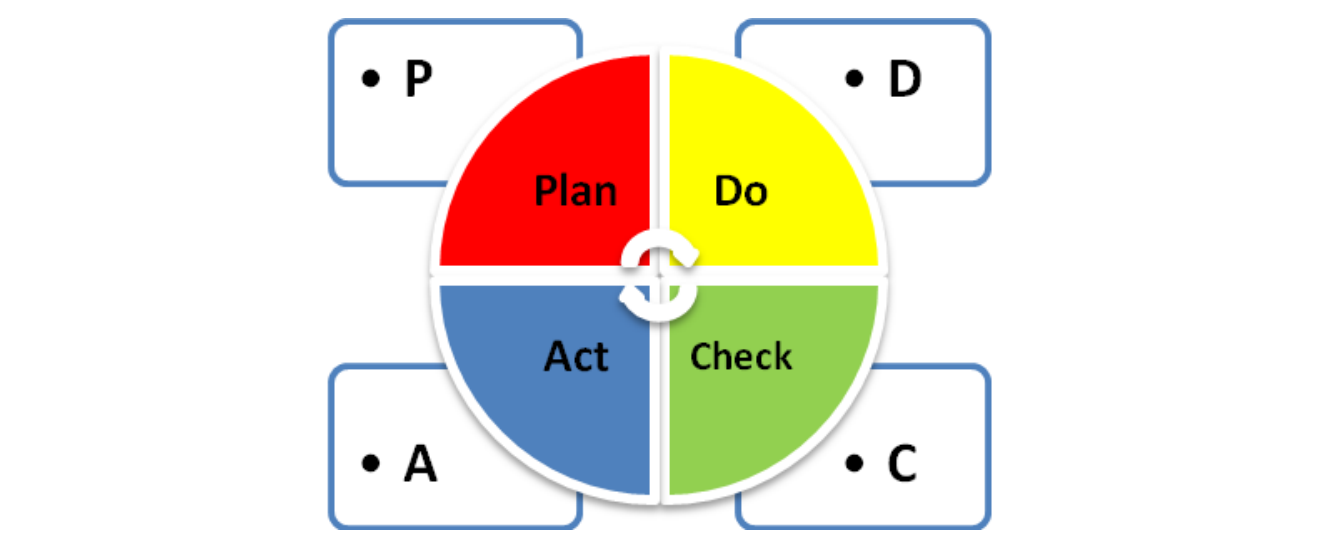

Gambar II.1. Siklus PDCA

Berikut ini adalah penjelasan singkat mengenai siklus PDCA (PDCA Cycle) dalam Heizer dan Render. ${ }^{4}$

a. Plan (merencanakan)

\footnotetext{
${ }^{3}$ Eliyanto, Manajemen \& Kepemimpinan Pendidikan Islam. (Kebumen: IAINU Kebumen, 2018).

${ }^{4}$ Heizer, Jay \& Render, Barry. Manajemen Operasi. Edisi Sembilan. Buku Dua. Diterjemahkan oleh Chriswan Sungkono. (Jakarta: Salemba Empat, 2011), hlm. 233.
} 
Tahap plan adalah tahap untuk menetapkan target atau sasaran yang ingin dicapai dalam peningkatan proses ataupun permasalahan yang ingin dipecahkan, kemudian menentukan metode yang akan digunakan untuk mencapai target atau sasaran yang telah ditetapkan tersebut. Dalam tahap plan ini juga meliputi pembentukan Tim Peningkatan Proses (Process Improvement Team) dan melakukan pelatihan-pelatihan terhadap sumber daya manusia yang berada di dalam Tim tersebut serta batas-batas waktu (Jadwal) yang diperlukan untuk melakukan perencanaan-perencanaan yang telah ditentukan. Perencanaan terhadap penggunaan sumber daya lainnya seperti biaya dan mesin juga perlukan dipertimbangkan dalam tahap plan ini.

Perencanaan merupakan fungsi paling awal dari keseluruhan fungsi manajemen sebagaimana banyak dikemukakan para ahli. Perencanaan adalah suatu proses mempersiapakan serangkaian keputusan untuk mengambil tindakan di masa yang akan datang diarahkan untuk tercapainya tujuan-tujuan dengan sarana yang optimal.

Menurut Roger A. Kauffman, Perencanaan adalah penentuan tujuan atau sasaran yang hendak dicapai dan menetapkan jalan serta sumber yang diperlukan untuk mencapai tujuan seefektif seefisien mungkin. ${ }^{5}$ Dalam setiap perencanaan selalu terdapat tiga kegiatan yang tidak dapat dipisahkan antara satu dengan yang lainnya dalam proses perencanaan. Ketiga kegiatan itu adalah: (1) perencanaan tujuan yang akan dicapai, (2) pemilihan program untuk mencapai tujuan, (3) identifikasi dan pengerahan sumber yang jumlahnya selalu terbatas.

Perencanaan merupakan tindakan menetapkan terlebih dahulu apa yang akan dikerjakan, bagaimana cara mengerjakannya, apa yang harus dan siapa yang mengerjakannya. Perencanaan sering juga disebut jembatan yang menghubungkan antara keadaan masa kini dan keadaan yang diharapkan terjadi pada masa yang akan datang. Perencanaan yang baik hendaknya memperhatikan sifat-sifat kondisi yang akan datang, dimana keputusan dan tindakan efektif dilaksanakan. Berdasarkan kurun waktunya dikenal perencanaan tahunan atau rencana jangka pendek (kurang dari lima tahun), rencana jangka menengah (lima sampai sepuluh tahun), rencana jangka panjang (di atas sepuluh tahun).

Beberapa metode yang digunakan secara umum dalam perencanaan dikemukakan oleh Augus W. Smith antara lain: (1) mean-ways-end-analysis, (2) inputoutput analysis, (3) econometric analysis, dan (4) life-cycle analysis. ${ }^{6}$ Metode-metode tersebut dapat digunakan dalam bidang pendidikan dengan melihat kecenderungankecenderungan dari berbagai aspek yang dapat dipertimbangkan untuk merumuskan

\footnotetext{
${ }^{5}$ Fattah, Nanang. Landasan Manajemen Pendidikan, cet. 1. (Bandung: Remaja Rosdakarya, 1996), hlm. 49.

${ }^{6}$ Ibid, hlm. 52.
} 
rencana dan program. Berikut ini penulis uraikan masing-masing.

\section{1) Metode mean-ways-end-analysis (analisis mengenai alat-cara-tujuan}

Metode ini digunakan untuk meneliti sumber-sumber dan alternatif untuk mencapai tujuan tertentu. Tiga hal yang perlu dianalisis dalam metode ini yaitu means yang berkaitan sumber-sumber yang diperlukan, ways yang berhubungan dengan cara dan alternatif tindakan yang dirumuskan dan bakal dipilih, dan yang berhubungan dengan tujuan yang hendak dicapai.

2) Metode input-output analysis ( analisis masukan dan keluaran )

Metode ini dilakukan dengan mengadakan pengkajian terhadap interelasi dan interpendensi berbabagai komponen masukan dan keluaran dari suatu sistem. Metode ini dapat digunakan untuk menilai alternatif dalam proses transformasi.

\section{3) Metode econometric analysis ( analisis ekonomerik )}

Metode ini menggunakan data empirik, teori, ekonomi, dan statistika, dalam mengukur perubahan dalam kaitannya dengan ekonomi. Metode ekonometrik mengembangkan persamaan-persamaan yang menggambarkan hubungan ketergantungan diantara variabel-variabel yang ada dalam suatu sistem.

4) Metode life-cycle analysis ( analisis siklus kehidupan )

Metode ini digunakan untuk mengalokasikan sumber-sumber dengan memperhatikan siklus kehidupan mengenai produksi, proyek, program, dan aktivitas. Dalam kaitannya ini sering digunakan bahan-bahan komparatif dengan menganalogkan data, langkah-langkah yang ditempuh dalam metode ini adalah fase:

(a) Konseptualisasi, (b) Spesifikasi, (c) Pengembangan prototipe, (d) Pengujian dan evaliasi, (e) Operasi, (f) Produksi.

b. Do (melaksanakan)

Tahap do adalah tahap penerapan atau melaksanakan semua yang telah direncanakan di tahap plan termasuk menjalankan prosesnya, memproduksi serta melakukan pengumpulan data (data collection) yang kemudian akan digunakan untuk tahap check dan act.

Pelaksanaan merupakan proses implementasi program agar bisa dijalankan oleh seluruh pihak dalam organisasi serta proses memotivasi agar semua pihak dapat bertanggung jawab dengan penuh kesadaran dan produktivitas yang tinggi. Proses memotivasi berarti mendorong semua pihak agar mau bekerja sama, ikhlas, dan bergairah untuk menvapai tujuan yang sesuai dengan rencaba-rencana yang telah ditentukan atau diorganisir sebelumnya.

Fungsi pelaksanaan ini menempuh posisi yang sangat penting dalam merealisasikan segenap tujuan organisasi.Actuating mencakup didalamnya adalah 
kepemimpinan, motivasi, dan komunikasi dalam rangka mempengaruhi seseorang untuk melakukan sesuatu guna mencapai tujuan organisasi.

Dilihat dari konteks manajemen sekolah, fungsi tersebut dijalankan oleh kepala sekolah, yakni melalui tindakan merangsang guru dan personal sekolah lainnya melaksanakan tugas-tugas dengan antusias dan kemauan yang baik untuk mencapai tujuan dengan penuh semangat. ${ }^{7}$

Kepala sekolah dalam menjalankan fungsinya perlu memperhatikan beberapa faktor seperti keefektifan organisasi kerja yang terdiri dari seluruh unit kerja (guru kelas, bimbingan penyuluhan, usaha kesehatan sekolah), kepekaan terhadap sejumlah kebutuhan pelayanan person sekolah, pelatihan guru, koordinasi yang meliputi pembagian kerja dan spesialisasi atau dasar tanggung jawab profesionalnya masingmasing, semangat kerjasama, tersedianya fasilitas dan kontak hubungan yang lancar bagi semua pihak dan memulai tahapan suatu kegiatan dengan benar dan mempertahankan kualitas pekerjaan sebagai proses yang kontinu. Jadi pelaksanaan adalah suatu usaha yang dilakukan pemimpin untuk memberikan penjelasan, petunjuk serta bimbingan kepada bawahannya sebelum dan selama melaksanakan tugas.

c. Check (memeriksa)

Tahap check adalah tahap pemeriksaan dan peninjauan ulang serta mempelajari hasil-hasil dari penerapan di tahap do. Melakukan perbandingan antara hasil aktual yang telah dicapai dengan target yang ditetapkan dan juga ketepatan jadwal yang telah ditentukan.

Pada tahap ini, tim menganalisis data yang dikumpulkan selama tahap Do (pelaksanaan). Hal tersebut untuk menemukan seberapa dekat hasilnya terhadap tujuan yang ditetapkan pada tahap Plan (perencanaan). Kemudian jika timbul kekurangan secara menyolok, maka tim harus mengevaluasi Plan dan menghentikan proyek. $^{8}$

Dalam langkah Check, tim melakukan pengawasan dan evaluasi atau menganalisis apa yang telah direncanakan dan pelaksanaannya. Menurut Krajewski dan Ritzman, langkah Check yaitu menganalisis data, untuk mengetahui kesesuaian antara perencanaan dengan pelaksanaan. ${ }^{9}$ Dengan demikian, tentu dalam langkah check terdapat langkah pengawasan dan evaluasi. Pengawasan yaitu meneliti dan mengawasi agar semua tugas dilakukan dengan baik dan sesuai dengan peraturan yang ada atau

\footnotetext{
${ }^{7}$ Sagala, Syaiful. Manajemen Strategik dalam Peningkatan Mutu Pendidikan. (Bandung: Alfabeta, 2010), hlm. 60 .

${ }^{8}$ Wibowo. Manajemen Kinerja. Edisi Kedua. (Jakarta: Raja Grafindo Persada, 2007), hlm. 281.

${ }^{9}$ Krajewski, Lee J. \& Ritzman, Larry. Operation Management: Strategy \& Analysis. (Addison-Wesley Publishing Company Inc, 1999), hlm. 19.
} 
sesuai dengan deskripsi kerja masing-masing personal. Sedangkan Evaluasi adalah pembuatan pertimbangan menurut suatu perangkat kriteria yang disepakati dan dapat dipertanggungjawabkan.

Pengawasan dilakukan dalam usaha menjamin semua bahwa kegiatan terlaksana sesuai dengan kebijaksanaan, strategi, keputusan, rencana, program kerja yang telah dianalisis, dan dirumuskan sebelumnya. Pengawasan yang baik memerlukan langkahlangkah yang meliputi:

1) Menentukan standar kualitas pekerja yang diharapkan. Standar tersebut dapat berupa standar fisik, standar biaya, standar model, standar penghasilan, dan standar program.

2) Mengukur dan mebilai kegiatan-kegiatan atas dasar tujuan dan standar yang ditetapkan.

3) Memutuskan dan mengadakan tindakan perbaikan. ${ }^{10}$

d. Act (menindaklanjuti)

Tahap act adalah tahap untuk mengambil tindakan yang seperlunya terhadap hasilhasil dari tahap check. Terdapat 2 jenis tindakan yang harus dilakukan berdasarkan hasil yang dicapainya, antara lain:

1) Tindakan Perbaikan (Corrective Action) yang berupa solusi terhadap masalah yang dihadapi dalam pencapaian Target, Tindakan Perbaikan ini perlu diambil jika hasilnya tidak mencapai apa yang telah ditargetkan.

2) Tindakan Standarisasi (Standardization Action) yaitu tindakan untuk menstandarisasi-kan cara ataupun praktek terbaik yang telah dilakukan, Tindakan Standarisasi ini dilakukan jika hasilnya mencapai Target yang telah ditetapkan. Siklus tersebut akan kembali lagi ke tahap plan untuk melakukan peningkatan proses selanjutnya sehingga terjadi siklus peningkatan proses yang terus menerus (Continuous Process Improvement).

Dalam langkah Act, tim merumuskan solusial ternatif yang dapat memperbaiki kelemahan-kelemahan yang ada dan meningkatkan kualitas keberhasilan pada masa yang akan datang. Menurut Wibowo, jika dalam pelaksanaan ternyata hasilnya sukses, amak tim perlu mendokumentasikan proses yang direvisi, sehingga menjadi prosedur standar. Selanjutnya, tim juga perlu menginstruksikan bagi siapa saja untuk menggunakan prosedur standar tersebut. ${ }^{11}$

Perbaikan perlu dilakukan secara berkelanjutan. Selanjutnya dikemukakan juga oleh Wibowo, bahwa kualitas adalah senjata untuk memenangkan persaingan. ${ }^{12}$ Jadi

\footnotetext{
${ }^{10}$ Machali, Imam \& Hidayat, Ara. Pengelolaan Pendidikan. (Yogyakarta: Kaukaba, 2012), hlm. 27.

${ }^{11}$ Wibowo, Op.Cit., hlm. 281.

${ }^{12} \mathrm{Ibid}, \mathrm{hlm} .276$.
} 
jelas bahwa kualitas perlu diutamakan. Pendidikan yang bermutu adalah pendidikan yang senantiasa melakukan perbaikan berkelanjutan.

\section{Sekolah Menengah Kejuruan}

Menurut Sukamto, pendidikan kejuruan adalah semua jenis dan bentuk pengalaman belajar yang membantu anak didik meniti tahap-tahap perkembangan vokasionalnya, mulai dari identifikasi, eksplorasi, orientasi, persiapan, pemilihan dan pemantapan karir di dunia kerja. ${ }^{13}$ Pendapat tersebut mengisyaratkan bahwa dunia pendidikan kejuruan sangat erat kaitannya dengan perkembangan karir lulusan setelah bekerja di dunia kerja dan industri (DUDI). Lulusan harus bekerja sesuai dengan bidang keahliannya agar karirnya dapat berkembang dengan pesat.

Sementara Wardiman Djojonegoro yang mengutip dari Rupert Evans mendifinisikan pendidikan kejuruan sebagai bagian dari sistem pendidikan yang mempersiapkan seseorang agar lebih mampu bekerja pada suatu kelompok pekerjaan atau satu bidang pekerjaan dari pada bidang-bidang pekerjaan lainya. ${ }^{14}$ Definisi lain oleh House Commite On Educational And Labour (HCEL) menyatakan bahwa pendidikan kejuruan adalah suatu bentuk pengembangan bakat, pendidikan dasar ketrampilan, dan kebiasaan-kebiasaan yang mengarah pada dunia kerja yang dipandang sebagai latihan keterampilan. ${ }^{15}$

Berdasarkan ketiga pendapat di atas dapat disimpulkan bahwa pendidikan kejuruan adalah bagian dari sisitem pendidikan untuk mempersipakan lulusannya mampu bekerja pada bidang tertentu. Dalam Undang-Undang Nomor 20 Tahun 2003 tentang Sistem Pendidikan Nasional Pasal 1 disebutkan jenjang pendidikan formal di Indonesia terdiri atas pendidikan dasar, pendidikan menengah, dan pendidikan tinggi. Dalam hal ini, pendidikan menengah terdiri atas pendidikan menengah umum dan pendidikan menengah kejuruan. Pendidikan menengah berbentuk Sekolah Menengah Atas (SMA), Madrasah Aliyah (MA), Sekolah Menengah Kejuruan (SMK), dan Madrasah Aliyah Kejuruan (MAK), atau bentuk lain yang sederajat. ${ }^{16}$

Secara khusus pengertian Sekolah Menengah Kejuruan (SMK) terdapat dalam Pasal 1 Peraturan Pemerintah Nomor 17 Tahun 2010 Tentang Pengelolaan Dan Penyelenggaraan Pendidikan sebagaimana telah diubah dalam Peraturan Pemerintah Nomor 66 Tahun 2010 Tentang Perubahan Atas Peraturan Pemerintah Nomor 17 Tahun 2010, SMK adalah salah satu bentuk satuan pendidikan formal yang menyelenggarakan pendidikan kejuruan pada jenjang pendidikan menengah sebagai lanjutan dari SMP, MTs,

\footnotetext{
${ }^{13}$ Usman, Husaini. Manajemen: Teori, Praktik, dan Riset Pendidikan. (Jakarta: Bumi Aksara, 2012), hlm. 6.

${ }^{14}$ Djojonegoro, Wardiman. Pengembangan Sumber Daya Manusia melalui Sekolah Menengah Kejuruan (SMK). (Jakarta: Jayakarta Agung, 1998), hlm. 33.

${ }^{15}$ Hamalik, Oemar. Evaluasi Kurikulum. (Bandung: Remaja Rosdakarya, 1990), hlm. 94.

${ }^{16}$ Indonesia, Republik. (2003). Undang-Undang Nomor 20 Tahun 2003 tentang Sistem Pendidikan Nasional.
} 
atau bentuk lain yang sederajat atau lanjutan dari hasil belajar yang diakui sama atau setara SMP atau MTs. ${ }^{17}$

Pada prinsipnya misi utama SMK adalah menyiapkan tenaga kerja tingkat menengah siap kerja. SMK memberikan bekal para siswanya dengan berbagai keahlian yang dibutuhkan di dunia kerja. Oleh karena itu, SMK memiliki berbagai bidang keahlian. Seperti disebutkan dalam Permendikbud Nomor 70 Tahun 2013 tentang Struktur Kurikulum SMK bahwa Bidang Keahlian pada SMK meliputi: Teknologi dan Rekayasa; Teknologi Informasi dan Komunikasi; Kesehatan Agribisnis dan Agroteknologi; Perikanan dan Kelautan; Bisnis dan Manajemen; Pariwisata; Seni Rupa dan Kriya; dan Seni Pertunjukan.Untuk mencapai misi tersebut, terdapat prinsip-prinsip yang harus diperhatikan dalam penyelenggaraan pendidikan SMK. ${ }^{18}$

\section{Mutu Pendidikan}

Dalam Bahasa Indonesia, mutu disebut juga kualitas. Sering juga dalam pengertian umum kata bermutu berarti mempunyai sifat yang baik atau terbaik. ${ }^{19}$ Mutu atau kualitas itu adalah merupakan paduan sifat-sifat produk yang menunjukkan kemampuan dalam memenuhi kebutuhan pelanggan langsung atau tidak langsung.

Mutu tidak terjadi begitu saja tetapi harus direncanakan. Dengan kata lain bahwa mutu harus menjadi bagian dari strategi institusi dan harus didekati secara sistematis dengan menggunakan perencanaan strategis. Mutu atau kualitas adalah merupakan paduan sifat-sifat produk yang menunjukkan kemampuan dalam memenuhi kebutuhan pelanggan langsung atau tidak langsung, baik kebutuhan yang dinyatakan maupun yang tersirat saat masa kini dan masa depan, ${ }^{20}$ atau mutu adalah sebuah proses terstruktur untuk memperbaiki keluaran yang dihasilkan. ${ }^{21}$

Tidak ada rangkaian aktifitas yang khusus dalam mengupayakan perencanaan strategi pengelolaan mutu meskipun berangkat dari hal yang bersifat filosofis menuju yang bersifat praktis bisa menjadi salah satu cara yang masuk akal. Meskipun demikian, menggunakan sebuah pendekatan Sistematis dalam merencanakan masa depan lembaga atau perusahaan merupakan hal yang penting. Strategi harus didasarkan kepada kelompok-kelompok pengguna.

\footnotetext{
17 Pemerintah, Peraturan. (2010). Peraturan Pemerintah Nomor 17 Tahun 2010 Tentang Pengelolaan Dan Penyelenggaraan Pendidikan sebagaimana telah diubah dalam Peraturan Pemerintah Nomor 66 Tahun 2010 Tentang Perubahan Atas Peraturan Pemerintah Nomor 17 Tahun 2010.

${ }^{18}$ Permendikbud Nomor 70 Tahun 2013 tentang Struktur Kurikulum SMK. Jakarta: Kemdikbud.

19 Tampubolon, Daulat P. Perguruan Tinggi Bermutu: Paradigma Baru Manajemen Pendidikan Tinggi Menghadapi Tantangan Abad ke-21. (Jakarta: Gramedia Pustaka Utama, 2001), hlm. 106.

${ }^{20}$ Ibid, hlm. 108.

${ }^{21}$ Arcaro, Jerome S. Pendidikan Berbasis Mutu: Prinsip-Prinsip Perumusan dan Tata Langkah Penerapan, cet. ke-2. (Yogyakarta: Pustaka Pelajar, 2007), hlm. 75.
} 
Mutu atau quality merupakan sebuah konsep yang kontradiktif karena di satu sisi mutu mutu dapat diartikan sebagai konsep yang absolut dan di sisi lain juga dapat diartikan sebagai konsep relatif. Mutu sebagai konsep absolut dapat dipahami sebagai dasar penilaian untuk kebaikan, kecantikan, dan kebenaran yang memungkinkan standar tinggi dan sempurna, sedangkan mutu sebagai konsep relatif adalah sebagai sebuah atribut produk atau layanan mutu yang dapat dinilai secara berkelanjutan atau mutu merupakan produk kontekstual. ${ }^{22}$

Banyak ahli yang mengemukakan tentang mutu atau yang sering diidentikan dengan kualitas, seperti yang dikemukakan oleh Edward Sallis, mutu adalah sebuah filsosofis dan metodologis yang membantu institusi untuk merencanakan perubahan dan mengatur agenda dalam menghadapi tekanan-tekanan eksternal yang berlebihan. ${ }^{23}$ Menurut Sudarwan Danim, mutu mengandung makna derajat keunggulan suatu produk atau hasil kerja, baik berupa barang dan jasa. ${ }^{24}$

Selanjutnya Lalu Sumayang menyatakan quality (mutu) adalah tingkat dimana rancangan spesifikasi sebuah produk barang dan jasa sesuai dengan fungsi dan penggunannya, di samping itu, quality adalah tingkat di mana sebuah produk barang dan jasa sesuai dengan rancangan spesifikasinya. ${ }^{25}$ "Sekolah yang berkualitas memiliki sumber daya yang sangat baik". ${ }^{26}$

Berkaitan dengan hal tersebut diatas, Tampubolon memberikan definisi mutu adalah "paduan sifat-sifat produk yang menunjukkan kemampuannya dalam memenuhi kebutuhan pelanggan, baik kebutuhan yang dinyatakan atau kebutuhan yang tersirat, masa kini dan masa depan". ${ }^{27}$ Akan tetapi pada dasarnya mutu atau kualitas dapat disamakan persepsinya melalui yang dikemukakan oleh Nasution, sebagai berikut :

a. Kualitas mencakup usaha memenuhi atau melebihi harapan pelanggan.

b. Kualitas mencakup produk, tenaga, kerja, proses, dan lingkungan.

c. Kualitas merupakan kondisi yang selalu berubah (misalnya apa yang dianggap memerlukan kualitas saat ini mungkin dianggap kurang berkualitas pada masa mendatang). ${ }^{28}$

\footnotetext{
${ }^{22}$ Machali, Imam \& Hidayat, Ara. (2016). The Handbook of Education Management. Jakarta: Prenadamedia Group.

${ }^{23}$ Sallis, Edward. Manajemen Mutu Pendidikan. (Yogyakarta: IRCiSod, 2008), hlm. 33.

${ }^{24}$ Danim, Sudarwan. Visi Baru Manajemen Sekolah. (Jakarta: Bumi Aksara, 2007), hlm. 53.

${ }^{25}$ Sumayang, Lalu. Dasar-dasar Manajemen Produksi dan Operasi. Edisi Pertama. (Jakarta: Salemba Empat, 2003), hlm. 322 .

${ }^{26}$ Eliyanto. Manajemen Sumber Daya Manusia (MSDM) Pendidikan. (Yogyakarta: Prodi MPI FITK UIN Sunan Kalijaga Yogyakarta, 2017), hlm. 4.

${ }^{27}$ Tampubolon, Daulat P., Op.Cit.

${ }^{28}$ Nasution. Manajemen Mutu Terpadu. (Jakarta: Ghalia Indonesia, 2005), hlm. 1.
} 
Sedangkan menurut Nana Sudjana, pengertian secara umum dapat diartikan suatu gambaran yang menjelaskan mengenai baik buruk hasil yang dicapai para siswa dalam proses pendidikan yang dilaksanakan. ${ }^{29}$

Mutu dapat didefinisikan sebagai sesuatu yang memuaskan dan melampaui keinginan dan kebutuhan pelanggan. ${ }^{30}$ Oleh karena mutu berkenaan dengan sifat kebaikan maka dapat dipahami bahwa makna itu berkaitan dengan aspek nilai yang berbeda dari suatu kebudayaan-kebudayaan lainnya bahkan dari indivivu ke individu lainnya. Menurut Sallis mutu yang relatif bukanlah sebuah akhir, namun sebagaimana sebuah alat dimana produk atau jasa dinilai, yaitu apakah telah memenuhi standar yang telah ditetapkan. ${ }^{31}$

Secara sederhana, bahwa mutu atau kualitas diartikan sebagai kesesuaian dengan persyaratan atau tuntutan, kecocokan untuk pemakaian, erbaikan atau penyempurnaan berkelanjutan, bebas dari kerusakan atau cacat. Secara absolut mutu dipahami sebagai dasar penelitian untuk kecantikan, kebaikan dan kebenaran, yang memiliki standar tinggi yang tidak dapat diungguli, sehingga produk dianggap bermutu bila dibuat sempurna meski tidak hemat biaya.

Secara relatif pemahaman terhadap mutu tidak hanya sebagai atribut produk atau layanan akan tetapi lebih dianggap sebagai sesuatu yang berasal dari mutu dan dapat dinilai secara berkelanjutan. Definisi relatif ini mengacu pada realitas adanya perbedaan antara kepentingan subyek penghasilan barang atau jasa dengan kepentingan pemakai barang. Mutu dalam pandangan seseorang terkadang bertentangan dengan mutu dalam pandangan orang lain. Satu hal yang dapat kita yakini bahwa mutu merupakan suatu hal yang dapat membedakan antara yang baik dan sebaliknya, bertolak dari kenyataan tersebut mutu dalam pendidikan akhirnya merupakan hal yang membedakan antara kesuksesan dan kegagalan.

Walaupun definisi mutu tersebut di atas tidak ada yang diterima secara universal, akan tetapi terdapat beberapa kesamaan, yaitu (a) Kualitas meliputi usaha memenuhi atau melebihi harapan pelanggan. (b) Kualitas mencakup produk, jasa, manusia, proses dan lingkungan. (c) Kualitas merupakan kondisi yang selalu berubah.

Kualitas didefinisikan sebagai totalitas dan karakteristik suatu produk yang menunjang kemampuannya untuk memuaskan kebutuhan yang dispesifikasikan atau ditetapkan. Jadi kualitas sering diartikan sebagai kepuasan pelanggan (customer satisfaction) atau konfirmasi terhadap kebutuhan atau persyaratan. Karena itu mutu

\footnotetext{
${ }^{29}$ Sudjana, Nana. Dasar-dasar Proses Belajar Mengajar. (Bandung: Sinar Baru Algensindo, 1998), hlm. 87.

${ }^{30}$ Sallis, Edward, Op.Cit., hlm. 56.

31 Usman, Husaini, Op.Cit., hlm. 408.
} 
diartikan sebagai kesesuaian paduan sifat-sifat produk dengan kebutuhan pelanggan (individu, masyarakat dan lain-lain).

Berdasarkan pendapat ahli di atas, dapat disimpulkan bahwa mutu (quality) adalah sebuah filsosofis dan metodologis, tentang (ukuran) dan tingkat baik buruk suatu benda atau jasa, yang membantu institusi untuk merencanakan perubahan dan mengatur agenda rancangan spesifikasi sebuah produk barang dan jasa sesuai dengan fungsi dan penggunannya agenda dalam menghadapi tekanan-tekanan eksternal yang berlebihan.

Dalam konteks pendidikan, konsep mutu mengharuskan penyelenggara pendidikan memahami dan menyadari bahwa produk lembaga pendidikan bukanlah barang, melainkan jasa atau layanan pendidikan.Peserta didik bukanlah produk lembaga pendidikan melainkan layanan yang mereka terima dan menjadikan mereka lulusan berkualitas.

Persoalan mutu merupakan tantangan penting dalam dunia pendidikan saat ini. Sebab mutu adalah indikator keberhasilan sistem pendidikan dalam dunia pendidikan termasuk di Indonesia.Mutu adalah agenda utama dan meningkatkan mutu merupakan tugas yang paling penting. Sehingga sangat wajar jika di era globalisasi ini ia menjadi satusatunya faktor pembeda yang dibutuhkan konsumen. Dalam konteks Total Quality Manajemen, mutu merupakan sebuah filosofi dan metodologi yang membantu institusi untuk merencanakan perubahan dan mengatur agenda dalam menghadapi tekanantekanan eksternal yang berlebihan.

Mutu pendidikan dasar dan menengah adalah tingkat kesesuaian antara penyelenggaraan pendidikan dasar dan menengah dengan Standar Nasional Pendidikan (SNP) pada satuan pendidikan dasar dan pendidikan menengah dan/atau program keahlian. Mutu pendidikan di satuan pendidikan tidak akan meningkat tanpa diiringi dengan penjaminan mutu pendidikan oleh satuan pendidikan.

Kata mutu memiliki pengertian yang bervariasi. Dalam hal ini Edward Sallis, mendefinsikan mutu sebagai sesuatu yang memuaskan dan melampaui keinginan dan kebutuhan pelanggan. ${ }^{32}$ Crosby dalam Engkoswara dan Aan Komariah, berpendapat bahwa mutu adalah kesesuaian individual terhadap persyaratan/ tuntutan, dengan mengatakan bahwa "quality is conformance to customer requirement". 33

Berdasarkan beberapa pengertian mutu di atas, dapat dipahami mutu adalah kemampuan dari barang atau jasa yang dapat memuaskan dan memenuhi kebutuhan pelanggan. Fokus mutu adalah kepuasan pelanggan, sehingga barang atau jasa dikatakan bermutu apabila mampu memuaskan, memenuhi, dan dapat bermanfaat baik bagi pelanggan. Dalam dunia pendidikan, yang disebut sebagai pelanggan secara khusus adalah

\footnotetext{
${ }^{32}$ Sallis, Edward. Op.Cit., hlm. 56.

${ }^{33}$ Engkoswara \& Aan Komariah. Administrasi Pendidikan. (Bandung: Alfabeta, 2010), hlm. 305.
} 
peserta didik. Seberapa puas peserta didik dalam merasakan kebermanfaatan penyelenggaraan pendidikan adalah perwujudan dari mutu pendidikan.

Engkoswara dan Aan Komariah berpendapat bahwa mutu pendidikan bersifat relatif karena tidak semua orang memiliki ukuran yang sama persis. ${ }^{34}$ Namun demikian apabila mengacu pada pengertian mutu secara umum dapat dinyatakan bahwa pendidikan yang bermutu adalah pendidikan yang seluruh komponennya memiliki persyaratan dan ketentuan yang diinginkan pelanggan dan menimbulkan kepuasan. Mutu pendidikan adalah baik, jika pendidikan tersebut dapat menyajikan jasa yang sesuai dengan kebutuhan para pelanggannya.

Prinsip Sistem Manajemen Mutu menurut ISO 9001 : 2015 ada Tujuh prinsip, yaitu: a). Customer Focus; b). Leadership; c). Engagement of People; d). Process Approach; e). Improvement; f). Evidence Based Decision Making; dan g). Relationship Management.

Dalam konteks ini pendidikan mutu mengacu kepada proses pendidikan dan hasil pendidikan, dalam proses pendidikan yang bermutu terlibat berbagai input seperti; bahan ajar (kognitif, afektif, psikomotorik), metodologi (bervariasi sesuai kemampuan guru), sarana sekolah, dukungan administrasi dan sarana prasarana dan sumber daya lainnya serta penciptaan yang kondusif. Manajemen sekolah, dukungan kelas berfungsi mensinkronkan berbagai input tersebut atau mensinergikan semua komponen dalam interaksi (proses) belajar mengajar baik antara guru, siswa dan sarana pendukung di kelas maupun di luar kelas, baik konteks kurikuler maupunekstrakurikuler, baik dalam lingkup substantsi yang akademis maupun non akademis dalam suasana yang mendukung proses pembelajaran.

Adapun mutu dalam konteks hasil pendidikan mengacu pada prestasi yang dicapai oleh sekolah pada setiap kurun waktu tertentu apakah tiap akhir semester, akhir tahun, 2 tahun atau 5 tahun, bahkan 10 tahun. Prestasi yang dicapai atau hasil pendidikan (student achievement) dapat berupa hasil test kemampuan akademis (misalnya undangan umum, middle, UAS). Dan dapat prestasi di bidang lain seperti prestasi di cabang olahraga, seni atau keterampilan tambahan misalnya: computer, jurnalistis, dan beragam jenis teknik, bahkan prestasi sekolah dan kondisi yang tidak dapat dipegang (intangible) seperti suasana disiplin, keakraban, saling menghormati, kebersihan dan sebagainya.

Proses dan hasil pendidikan yang bermutu saling berhubungan, akan tetapi agar proses yang baik dan tidak salah arah, maka mutu dalam artian hasil (out put) harus dirumuskan lebih dahulu oleh lembaga, dan harus jelas target yang akan dicapai untuk setiap tahun atau kurun waktu lainnya. Berbagai input dan proses harus selalu mengacu pada mutu hasil (out put) yang ingin dicapai, dengan kata lain tanggung jawab sekolah dalam school based quality improvement bukan hanya pada proses, tetapi tanggung jawab

\footnotetext{
${ }^{34}$ Ibid.
} 
akhirnya adalah pada hasil yang dicapai. Untuk mengetahui hasil/prestasi yang dicapai oleh sekolah terutama yang menyangkut aspek kemampuan akademik dan kognitif dapat dilakukan benchmarking (menggunakan titik acuan standar). Evaluasi terhadap seluruh hasil pendidikan pada setiap sekolah baik yang sudah ada patokannya (benchmarking) maupun yang lain (kegiatan ekstra kurikuler) dilakukan oleh individu sekolah sebagai evaluasi diri dan dimanfaatkan untuk memperbaiki target mutu dan proses pendidikan. Adapun secara konsepsional upaya peningkatan mutu pendidikan harus dilakukan secara menyeluruh meliputi seluruh komponen penyelenggaraan pendidikan yaitu input, proses, dan out put dengan semua perangkat yang mendukungnya melalui kepala sekolah, guru, tenaga kependidikan, kurikulum, sarana prasarana pendidikan.

Mutu pendidikan pada Pendidikan Dasar dan Menengah dilihat dari tingkat kesesuaian antara penyelenggaraan Pendidikan Dasar dan Menengah dengan Standar Nasional Pendidikan (SNP) pada satuan Pendidikan Dasar dan Pendidikan Menengah dan/atau program keahlian. SNP memuat kriteria minimal tentang komponen pendidikan yang memungkinkan setiap jenjang dan jalur pendidikan untuk mengembangkan pendidikan secara optimal sesuai dengan karakteristik dan kekhasan programnya. ${ }^{35}$ Lingkup SNP meliputi: standar isi, standar proses, standar kompetensi lulusan, standar pendidik dan tenaga kependidikan, standar sarana dan prasarana, standar pengelolaan, standar pembiayaan, dan standar penilaian pendidikan.

\section{METODE PENELITIAN}

Pendekatan yang digunakan dalam penelitian ini adalah adalah penelitian kualitatif, yaitu suatu pendekatan ilmiah yang mengungkap situasi sosial tertentu dengan mendeskripsikan kenyataan secara benar, dibentuk oleh kata-kata berdasarkan teknik pengumpulan analisis data yang relevan yang diperoleh dari situasi yang alamiah. Waktu penelitian adalah antara bulan Januari 2019 sampai dengan bulan September 2019, dan tempat penelitian adalah di SMK Ma`arif NU 1 Bener, yang beralamat di Jl. Magelang km 12 Kaliboto Bener Kabupaten Purworejo. Provinsi Jawa Tengah. Hal ini disebabkan sekolah tersebut merupakan Sekolah Menengah kejuruan Swasta, masih baru akan tetapi mengalami perkembagan yang cukup signufikan. Selain itu, letak geografis SMK Ma`arif NU 1 Bener Purworejo yang berada di daerah kecamatan, tidak berada di daerah perkotaan namun justru dapat mearik perhatian masyarakat banyak.

Subjek dan informan penelitian ini yaitu orang-orang yang benar-benar mengetahui permasalahan yang akan diteliti. Sumber data dalam penelitian ini menggunakan data primer yaitu berupa wawancara langsung kepada Ketua Yayasan Maarif NU Bener Purworejo; Wakil Kepala Hubinmas; Guru; Peserta didik; Komite SMK Maarif NU 1 Bener.

\footnotetext{
${ }^{35}$ Machali, Imam \& Hidayat, Ara. (2016), Op.Cit., hlm. 311.
} 
Teknik pengumpulan data merupakan cara yang digunakan peneliti untuk memperoleh data penelitian yang dibutuhkan. Proses pengumpulan data dalam penelitian ini dilakukan dengan: observasi, wawancara mendalam, dan dokumentasi.

Dalam menguji keabsahan data peneliti menggunakan tehnik Triangulasi, yakni teknik pemeriksaan keabsahan data yang memanfaatkan sesuatu yang lain diluar data untuk keperluan pengecekan atau sebagai pembanding terhadap data itu. Itu artinya melakukan validasi, dengan cara mengecek dokumen program dan bukti tertulis lainnya. ${ }^{36}$ Dalam penelitian ini menggunakan Triangulasi metode yaitu menggunakan dua strategi yaitu: (1) Pengecekan terhadap derajat kepercayaan penemuan hasil penelitian dengan beberapa tehnik pengumpulan data; (2) Pengecekan derajat kepercayaan beberapa sumber data dengan metode yang sama.

Langkah-langkah yang dilakukan penulis lakukan untuk menganalisis data yang sudah diperoleh dari hasil observasi, wawancara, dan dokumentasi yaitu dengan menggunakan model analisis data Miles dan Huberman sebagaimana yang dikutip oleh Sugiyono, yaitu reduksi data (data reduction), penyajian data (data display), dan penarikan kesimpulan (conclusion drawing/verification). ${ }^{37}$

\section{HASIL PENELITIAN DAN PEMBAHASAN}

Manajemen Mutu SMK Maarif NU 1 Bener Purworejo dilaksanakan dengan menggunakan langkah-langkah perencanaan, pelaksanaan, evaluasi, dan tindak lanjut. Adapun pembahasan selengkapnya adalah sebagai berikut.

\section{Perencanaan SMK Maarif NU 1 Bener Purworejo dalam Meningkatkan Mutu Pendidikan dan Kepercayaan Masyarakat}

Terdapat tiga tahap perencanaan yang dilakukan oleh SMK Maarif NU 1 Bener Purworejo dalam upaya pencapaian mutu penddidikan dan kepercayaan masyarakat, yaitu: (a) penetapan standar mutu, (b) pemetaan mutu, dan (c) penyusunan rencana pemenuhan mutu. Berikut ini penulis uraikan masing-masing.

a. Penetapan Standar Mutu SMK Maarif NU 1 Bener Purworejo

Penetapan standar mutu pendidikan dimaksudkan untuk mengukur dan menilai pemenuhan standar sebagaimana yang telah ditetapkan dalam kebijakan mutu. Pada tahap penetapan standar mutu, SMK Maarif NU 1 Bener Purworejo mempertimbangkan kebutuhan sekolah dan melibatkan para stakeholder sekolah, seperti komite sekolah, masyarakat, pemerintah, dan dunia industri.

Penetapan standar mutu di SMK Maarif NU 1 Bener Purworejo mengacu pada Standar Nasional Pendidikan, sebagaimana dijelaskan dalam Pasal 1 Peraturan Pemerintah Nomor 13 Tahun 2015, yang meliputi: Standar Isi, Standar Proses, Standar Kompetensi Lulusan, Standar Pendidik dan Tenaga Kependidikan, Standar

\footnotetext{
${ }^{36}$ Patton, Michael Quinn. Metode Evaluasi Kualitatif. (Yogyakarta: Pustaka Pelajar, 2006), hal. 280.

37 Sugiyono, Metode Penelitian Pendidikan, (Bandung: Alfabeta. 2009), hal. 254.
} 
Sarana dan Prasarana, Standar Pengelolaan, Standar Pembiayaan, dan Standar Penilaian Pendidikan.

b. Pemetaan Mutu SMK Maarif NU 1 Bener Purworejo

Langkah-langkah yang dilakukan SMK Maarif NU 1 Bener Purworejo dalam melaksanakan pemetaan mutu, yaitu: penyusunan instrumen, pengumpulan data, pengolahan dan analisa data serta penyusunan hasil. Sekolah menyusun instrumen yang mencakup seluruh standar beserta indikator dari masing-masing standar. Penyusunan instrumen ini digunakan untuk membantu dalam mengembangkan proses pemetaan mutu sekolah.

Pemetaan mutu SMK Maarif NU 1 Bener Purworejo dilaksanakan melalui kegiatan Evaluasi Diri Sekolah, yang mengacu pada SNP. Pemetaan mutu melibatkan seluruh komponen satuan pendidikan dan pemangku kepentingan, seperti: kepala sekolah, guru, karyawan sekolah, komite sekolah, peserta didik, yayasan, pengawas sekolah, serta dunia usaha dunia industri. Pemetaan mutu ini dilakukan berdasarkan bukti-bukti fisik yang telah dikumpulkan secara sistematis. Selanjutnya, hasil pemetaan mutu dari EDS tersebut disajikan secara singkat dan informatif. Hasil analisa data bukti tersebut menggambarkan peta capaian mutu SMK Maarif NU 1 Bener Purworejo terhadap standar, masalah-masalah yang dihadapi, serta rekomendasi perbaikannya.

c. Penyusunan Rencana Pemenuhan Mutu SMK Maarif NU 1 Bener Purworejo

Pada tahap ini, Tim Penjaminan Mutu Pendidikan Sekolah melalui tim pengembang sekolah menganalisis informasi yang telah dikumpulkan dan mempergunakannya untuk mengidentifikasi dan memprioritaskan bidang yang membutuhkan perhatian, yang kemudian akan menjadi dasar bagi rencana pemenuhan mutu. Selain itu, rencana pemenuhan mutu disusun berdasarkan evaluasi diri satuan pendidikan, kebijakan pemerintah pusat dan daerah, serta visi, misi dan kebijakan satuan pendidikan.

Rencana pemenuhan mutu SMK Maarif NU 1 Bener Purworejo berisikan tanggung jawab untuk pelaksanaannya, dilengkapi dengan kerangka waktu, tenggang waktu dan ukuran keberhasilan. Lebih lanjut, bentuk dari rencana pemenuhan mutu dapat berupa rencana kerja tahunan yang merupakan penjabaran rinci dari rencana kerja menengah satuan pendidikan yang meliputi masa 4 (empat) tahun. Adapun rencana pemenuhan mutu tersebut diwujudkan dalam bentuk RKS, yang berupa RKJM/RKT. Penyusunan RKS tersebut disusun secara sistematis dan mencakup berbagai komponen yang diperlukan, yaitu melalui tiga jenjang, yaitu: persiapan, penyusunan, dan pengesahan.

2. Pelaksanaan SMK Maarif NU 1 Bener Purworejo dalam Meningkatkan Mutu Pendidikan dan Kepercayaan Masyarakat 
Pelaksanaan merupakan tahapan kedua setelah perencanaan. Pelaksanaan pemenuhan mutu SMK Maarif NU 1 Bener Purworejo merupakan realisasi seluruh program dan kegiatan yang telah dirancang dan telah tertuang dalam dokumen perencanaan pemenuhan mutu sekolah. Seluruh pemangku kepentingan (stakeholder) sekolah memiliki komitmen untuk mengimplementasikan pemenuhan mutu sekolah.

Proses implementasi perencanaan pemenuhan mutu tersebut dijabarkan dan diatur pelaksanaannya mulai dari level ruang kelas, level antar jenjang kelas dan level sekolah. Hal tersebut dilakukan agar pelaksanaan perencanaan berjalan optimal. Selanjutnya, untuk Rencana pelaksanaan dan pemantauan program serta kegiatan sekolah juga selalu disosialisasikan kepada seluruh pemangku kepentingan. Pelaksanaan SMK Maarif NU 1 Bener Purworejo dalam meningkatkan mutu pendidikan dan kepercayaan masyarakat yaitu dengan pemenuhan Standar Isi, Standar Proses, Standar Kompetensi Lulusan, Standar Pendidik dan Tenaga Kependidikan, Standar Sarana dan Prasarana, Standar Pengelolaan, Standar Penilaian Pendidikan, dan Standar Pembiayaan.

\section{Evaluasi SMK Maarif NU 1 Bener Purworejo dalam Meningkatkan Mutu}

\section{Pendidikan dan Kepercayaan Masyarakat}

Evaluasi merupakan tahapan penting dalam manajemen. Evaluasi pemenuhan mutu merupakan tahapan pengujian yang sistematis dan independen untuk mengetahui capaian target yang telah ditetapkan. Evaluasi merupakan kegiatan membandingkan dan menilai antara hasil aktual yang telah dicapai dengan target yang ditetapkan, juga dengan ketepatan waktu/jadwal yang telah ditentukan. Melalui evaluasi akan diketahui evektifitas suatu program. Evaluasi pemenuhan mutu dilakukan oleh SMK Maarif NU 1 Bener Purworejo untuk melihat kinerja sekolah dan mengetahui tahapan pengembangan dalam pencapaian 8 SNP.

Evaluasi pemenuhan mutu dilakukan oleh SMK Maarif NU 1 Bener Purworejo yaitu melalui Evaluasi Diri Sekolah. Sekolah membentuk tim pelaksana evaluasi, menyusun instrumen evaluasi, dan melakukan evaluasi. Pada tahap ini, sekolah mengidentifikasi bukti-bukti fisik keadaan sekolah, melakukan pemeriksaan dan peninjauan ulang serta mempelajari hasil-hasil dari pelaksanaan pemenuhan mutu.

\section{Tindak Lanjut SMK Maarif NU 1 Bener Purworejo dalam Meningkatkan Mutu}

\section{Pendidikan dan Kepercayaan Masyarakat}

Tindak lanjut pemenuhan mutu yang dilakukan oleh SMK Maarif NU 1 Bener Purworejo dalam meningkatkan mutu pendidikan dan kepercayaan masyarakat yaitu dengan mengambil langkah perbaikan. Tindak lanjut ini dilakukan setelah adanya evaluasi. Dalam tahap tindak lanjut pemenuhan mutu ini, sekolah berupaya meningkatkan mutu pendidikan secara berkelanjutan.

Terdapat dua jenis kegiatan yang dilakukan oleh SMK Maarif NU 1 Bener Purworejo dalam menindak-lanjuti hasil evaluasi, yaitu: (a) Tindakan perbaikan (corrective action), yaitu berupa solusi pemecahan masalah yang terjadi. Hal ini 
dilakukan jika hasil kerja belum sesuai yang ditargetkan. (b) Tindakan standarisasi (standardization ancion), yaitu berupa menstandarisasikan cara / praktik terbaik yang telah dilakukan, untuk kemudian ditingkatkan. Hal ini dilakukan jika hasil kerja sesuai target yang ditetapkan. Tindakan ini (perbaikan dan standarisasi) merupakan siklus yang terus-menerus dilakukan untuk peningkatan mutu pendidikan.

\section{F. KESIMPULAN}

Berdasarkan analisis data dan pembahasan yang diperoleh dalam penelitian ini, maka dapat diambil kesimpulan sebagai berikut:

1. Perencanaan SMK Maarif NU 1 Bener Purworejo dalam Meningkatkan Mutu Pendidikan dan Kepercayaan Masyarakat dilakukan melalui tiga tahapan, yaitu: Pertama, Penetapan standar mutu, yang mengacu pada 8 Standar Nasional Pendidikan. Kedua, Pemetaan mutu, yang didasarkan pada hasil Evaluasi Diri Sekolah dan SNP (Standar Nasional Pendidikan). Ketiga, Penyusunan rencana pemenuhan mutu.

2. Pelaksanaan SMK Maarif NU 1 Bener Purworejo dalam Meningkatkan Mutu Pendidikan dan Kepercayaan Masyarakat dilakukan melalui pemenuhan Standar Isi, Standar Proses, Standar Kompetensi Lulusan, Standar Pendidik dan Tenaga Kependidikan, Standar Sarana dan Prasarana, Standar Pengelolaan, Standar Penilaian Pendidikan, Standar Pembiayaan. Selanjutnya, seluruh komponen sekolah juga memiliki komitmen tinggi dalam pelaksanaan pemenuhan mutu tersebut.

3. Evaluasi SMK Maarif NU 1 Bener Purworejo dalam Meningkatkan Mutu Pendidikan dan Kepercayaan Masyarakat dilakukan melalui Evaluasi Diri Sekolah. Pada tahap ini, sekolah menyusun instrumen evaluasi kemudian membentuk tim pelaksana evaluasi.

4. Tindak Lanjut SMK Maarif NU 1 Bener Purworejo dalam Meningkatkan Mutu Pendidikan dan Kepercayaan Masyarakat dilakukan sebagai suatu siklus yang berkelanjutan, yaitu melalui: (a) Corrective Action, tindakan perbaikan ini dilakukan jika hasilnya tidak mencapai apa yang telah ditargetkan; (b) Standardization Action, tindakan perbaikan ini dilakukan jika hasilnya mencapai target yang telah ditetapkan.

\section{DAFTAR PUSTAKA}

Arcaro, Jerome S. (2007), Pendidikan Berbasis Mutu: Prinsip-Prinsip Perumusan dan Tata Langkah Penerapan, cet. ke-2. Yogyakarta: Pustaka Pelajar.

Danim, Sudarwan. (2007). Visi Baru Manajemen Sekolah. Jakarta: Bumi Aksara.

Djojonegoro, Wardiman. (1998). Pengembangan Sumber Daya Manusia melalui Sekolah Menengah Kejuruan (SMK). Jakarta: Jayakarta Agung.

Eliyanto, (2018). Manajemen \& Kepemimpinan Pendidikan Islam. Kebumen: IAINU Kebumen.

, (2017). Manajemen Sumber Daya Manusia (MSDM) Pendidikan. Yogyakarta: Prodi MPI FITK UIN Sunan Kalijaga Yogyakarta. 
Engkoswara \& Aan Komariah. (2010). Administrasi Pendidikan. Bandung: Alfabeta.

Fattah, Nanang. (1996). Landasan Manajemen Pendidikan, cet. 1. Bandung: Remaja Rosdakarya.

Gaspersz, Vincent (2002). Pedoman Implementasi Program SIX SIGMA Terintegrasi dengan ISO 9001 : 2000, MBNQA, dan HACCP. Jakarta: Gramedia Pustaka Utama.

Hamalik, Oemar. (1990). Evaluasi Kurikulum. Bandung: Remaja Rosdakarya.

Heizer, Jay \& Render, Barry. (2011). Manajemen Operasi. Edisi Sembilan. Buku Dua. Diterjemahkan oleh Chriswan Sungkono. Jakarta: Salemba Empat.

Indonesia, Republik. (2003). Undang-Undang Nomor 20 Tahun 2003 tentang Sistem Pendidikan Nasional.

Krajewski, Lee J. \& Ritzman, Larry. (1999). Operation Management: Strategy \& Analysis. Addison-Wesley Publishing Company Inc.

Machali, Imam \& Hidayat, Ara. (2012). Pengelolaan Pendidikan. Yogyakarta: Kaukaba. . (2016). The Handbook of Education Management. Jakarta: Prenadamedia Group.

Nazarudin. 2007. Manajemen Pembelajaran: Implementasi Konsep, Karakteristik, dan Metodologi Pendidikan Agama Islam. Yogyakarta: Teras.

Nasution. (2005). Manajemen Mutu Terpadu. Jakarta: Ghalia Indonesia.

Sallis, Edward. (2008). Manajemen Mutu Pendidikan. Yogyakarta: IRCiSod.

Sudjana, Nana. (1998). Dasar-dasar Proses Belajar Mengajar. Bandung: Sinar Baru Algensindo.

Sumayang, Lalu. (2003). Dasar-dasar Manajemen Produksi dan Operasi. Edisi Pertama. Jakarta: Salemba Empat.

Usman, Husaini. (2012). Manajemen: Teori, Praktik, dan Riset Pendidikan. Jakarta: Bumi Aksara.

Patton, Michael Quinn, (2006), Metode Evaluasi Kualitatif, Yogyakarta: Pustaka Pelajar.

Pemerintah, Peraturan. (2010). Peraturan Pemerintah Nomor 17 Tahun 2010 Tentang Pengelolaan Dan Penyelenggaraan Pendidikan sebagaimana telah diubah dalam Peraturan Pemerintah Nomor 66 Tahun 2010 Tentang Perubahan Atas Peraturan Pemerintah Nomor 17 Tahun 2010.

Permendikbud. (2013). Permendikbud Nomor 70 Tahun 2013 tentang Struktur Kurikulum SMK. Jakarta: Kemdikbud.

Sagala, Syaiful. (2010). Manajemen Strategik dalam Peningkatan Mutu Pendidikan. Bandung: Alfabeta.

Sugiyono, (2009), Metode Penelitian Pendidikan, Bandung: Alfabeta.

Tampubolon, Daulat P. (2001). Perguruan Tinggi Bermutu: Paradigma Baru Manajemen Pendidikan Tinggi Menghadapi Tantangan Abad ke-21. Jakarta: Gramedia Pustaka Utama. Wibowo. (2007). Manajemen Kinerja. Edisi Kedua. Jakarta: Raja Grafindo Persada. 